\title{
Researching the effect of the practical applications performed with cadaver dissection and anatomical models on anatomy education
}

\section{Kadavra disseksiyonu ve anatomilk modellerle yapılan pratik uygulamaların anatomi eğitimine etkisinin araştırılması}

Vedat Sabancığulları *, Selma Çetinkaya **, Güldal Doğruyol *, Kağan Çimen *, Muhittin Sönmez *, Mehmet Çimen*

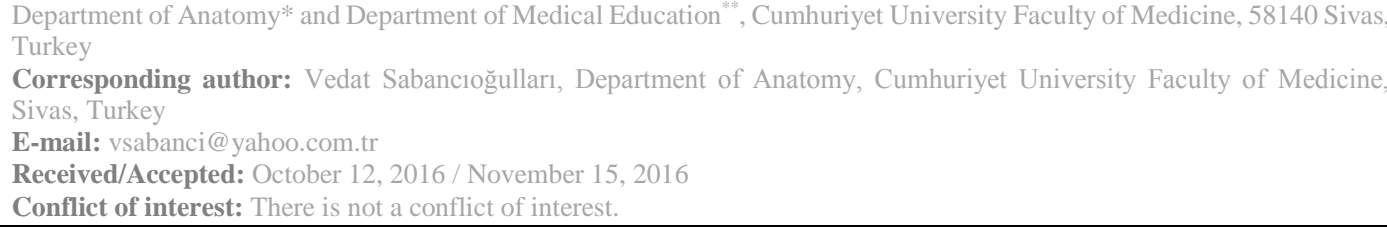

\section{SUMMARY}

Objective: The most important element in providing good quality of healthcare is well training of healthcare staff, particularly doctors. The way of being a good and successful healthcare staff is to learn the human anatomy accurately and permanently. Practical applications as well as theoretical courses are also highly important in learning human anatomy. In classical anatomy education, using cadaver is accepted to be indispensable. However, along with the new medical faculties, there has been an increase in the shortage of cadaver, and anatomy practices have mainly begun to be carried out on models or mock-ups. Therefore, we aimed to study with anatomic models in practical applications and to research the effect of cadaver dissection on learning anatomy.

Method: In this study including 120-second grade students that their achievement levels are close together and participating in the theoretical courses of anatomy in medical faculty during 2015 2016 academic year. To realize this, students were divided into four groups $\left(1^{\text {st }}\right.$ group were include students only listening to theoretical course, $2^{\text {nd }}$ group theoretical course and performing application with anatomic models, $3^{\text {rd }}$ group theoretical course and performing application with cadaver dissection, and $4^{\text {th }}$ group theoretical course and performing application with anatomic models and cadaver dissection) of 30 people.

Degree of students' understanding the subject was detected with written and practical exams consists of 10 questions after the theoretical and practical courses on each committee. The resulting data are loaded to SPSS 22.0 software and statistical evaluation One-way ANOVA, Mann-Whitney, chisquare test was used.

Results: The average of students who practice on both models and cadavers were statistically significant $(\mathrm{p}<0.05)$ higher than others in the course committee of the circulatory system. The average point of the students in Group III and IV were statistically significant higher than the other two groups ( $\mathrm{p}<0.05$ ), in the course committee of sensory and nervous systems. Although the average scores of males were lower than females this difference was not statistically significant $(\mathrm{p}>0.05)$. 
Conclusions: The results obtained from our study indicate that anatomy practical training is carried out with the dissection of cadavers that made it easier to understand of the anatomy and increasing success rate. The results obtained from the study give information about the effectiveness of existing applications in anatomy practice and be a guide for educators in planning class hours and including or excluding new topics and subjects from curriculum.

"This work was supported by the Scientific Research Project Fund of Cumhuriyet University under the Project number "RGD-7".

Keywords: Cadaver, Anatomy Education, Anatomical Models.

\section{ÖZET}

Amaç: Kaliteli sağl1k hizmeti verilebilmesinde en önemli unsur, başta doktorlar olmak üzere sağlık personelinin iyi yetişmiş olmasıdır. Mesleğinde başarılı, iyi bir sağlık elemanı olmanın yoluda insan anatomisini doğru ve kalıcı bir şekilde öğrenmekten geçer. İnsan anatomisini öğrenmede teorik derslerin yanı sıra pratik uygulamalarda çok önemlidir. Klasik anatomi eğitiminde kadavra kullanımı vazgeçilmez olarak kabul edilmektedir. Ancak yeni tıp fakültelerinin açılmasıyla kadavra sıkıntısı artmış ve anatomi pratikleri ağırlıklı olarak maketler üzerinde yapılmaya başlanmıştır. Bu sebeple pratik uygulamalar içerisinde yer alan anatomik modellerle çalışma ve kadavra disseksiyonlarının anatomiyi öğrenmeye olan etkisini araştırmayı amaçladık.

Yöntem: 2015-2016 eğitim- öğretim dönemi içerisinde, başarı düzeyleri birbirine yakın olan ve anatomi teorik derslerini takip eden 120 tıp fakültesi ikinci sınıf öğrencisi çalıșmaya dahil edildi. Öğrenciler 30'ar kişilik dört grup (1. grup sadece teorik ders dinleyenler, 2.grup teorik ders ve anatomik modellerle uygulama yapanlar 3.grup teorik ders ve kadavra diseksiyonuyla uygulama yapanlar 4.grup teorik ders, anatomik modeller ve kadavra diseksiyonuyla uygulama yapanlar)'a ayrild1.

Her bir ders kurulunda verilen teorik dersler ve pratik uygulamalardan sonra, 10 sorudan oluşan, pratik sinavlarla öğrencilerin konuyu anlama dereceleri tespit edildi. Elde edilen veriler SPSS 22.0 programına yüklendi ve istatistiksel değerlendirmede Oneway Anova, Mann-Whitney U, Khi-kare testi kullanıldı.

Bulgular: Dolaşım sistemi ders kurulunda, teorik dersten sonra, hem maket hemde kadavra üzerinde pratik uygulama yapan öğrencilerin not ortalaması diğerlerinden belirgin şekilde daha yüksekti. Aradaki bu fark istatistiksel olarakta anlamlıydı $(\mathrm{p}<0.05)$. Duyu ve sinir sistemleri ders kurulunda ise, grup III ve IV'ü oluşturan öğrencilerin not ortalaması istatistiksel olarak anlamlı bir şekilde, diğer iki gruptan daha yüksekti $(\mathrm{p}<0.05)$. Gruplardaki kız ve erkeklerin başarı durumları karşılaştırıldığında ise, erkeklerin ortalama puanları daha düşük olmakla beraber bu fark istatistiksel olarak anlamlı değildi $(\mathrm{p}>0.05)$

Sonuç: Çalışmamızdan elde edilen sonuçlar, kadavra diseksiyonu yapılarak verilen anatomi pratik eğitimlerinin anlamayı kolaylaştırdığı ve başarıyı arttırdığını göstermektedir. Çalışmadan elde edilen bu sonuç, anatomi pratiğinde mevcut uygulamaların etkinliği konusunda bilgi verdiği gibi, ders saatlerinin planlanmasında, müfredata yeni konular eklenmesi ya da çıkarılması noktasındada eğitimcilere yol gösterici olacaktır.

Anahtar sözcükler: Kadavra, Anatomi eğitimi, Anatomik modeller.

Bu çalışma Proje No "RGD-7 adıyla Cumhuriyet Üniversitesi Bilimsel Araştırma Projeleri Fonu tarafindan desteklenmiştir.

\section{INTRODUCTION}

Anatomy education has maintained its importance for thousands of years in parallel with the advances in medicine. With the diversification of sub-branches in medicine, there have been changes in the duration and methods in anatomy education over time. However, practices on cadaver as an unchanging method of anatomy practice education have been accepted for years ${ }^{1-3}$.

Advanced technology supports and gives variety on the practical anatomy education on cadaver. Thanks to today's technological opportunities, more distinguished models and detailed computer programs were created. Bacro et al. noted that computer-assisted 
training both decrease the costs and prevent the waste of time ${ }^{2,4}$.

However, no matter how excellent the computer programs are, the view that they could not replace with the training on human cadaver is more dominant. Opening of the new medical faculties, increase in the student quotas in present faculties, and difficulties in the provision of cadaver in country have increased the problem of cadaver and created great challenges on the medical training. Thus, anatomy classes accepted as basic training in medical faculties have been given heavily on models due to the inadequacy in the numbers of cadaver ${ }^{2,3}$. Therefore, we aimed at studying the efficiency of cadaver dissections and practical applications performed with anatomical models in anatomy education.

\section{MATERIAL AND METHODS}

The study included the 120 second-grade students in medical faculty who took the anatomy theoretical class in $2015-2016$ academic year and whose success levels are close to each other. The students were divided into 4 groups; 1) those listening only theoretical classes, 2) those listening theoretical classes and practising with anatomical models, 3) those listening theoretical classes and practising with cadaver dissections, 4) those listening theoretical classes and practising with anatomical models and cadaver dissections.

Following the each theoretical classes and practices on anatomical model and cadaver, students were tested with practical exams in order to determine their level of comprehension. Ten questions with the same points were asked to the students in the exam held in anatomy laboratory. The questions were asked to the students by means of pricking numbered needles to the anatomical models on the table. The response time were 30 seconds for each question. One point was given for each correct answer, and total scores of each student were calculated. SPSS 22.0 was used to statistically evaluate the 120 students' scores. Oneway ANOVA, Mann-Whitney $\mathrm{U}$ and Chi-square tests were used in statistical evaluation.

\section{RESULTS}

Of 120 medical school second-grade students, 60 were female and 60 were male. Their average age was $20.43 \pm 1.73$ (19-29 years old). There were 15 female and 15 male students in each group.

Table 1. According to the committees the average success of the groups.

\begin{tabular}{|l|ll|ll|ll|ll|}
\hline Committees & $\begin{array}{l}\text { Group 1 } \\
\text { (n=30) }\end{array}$ & $\begin{array}{l}\text { Group 2 } \\
\text { (n=30) }\end{array}$ & $\begin{array}{l}\text { Group 3 } \\
(\mathbf{n = 3 0})\end{array}$ & $\begin{array}{l}\text { Group 4 } \\
(\mathbf{n = 3 0 )}\end{array}$ \\
\hline Tissue biology committee & 6.14 & \pm & 6.60 & \pm & 7.49 & \pm & 7.97 & \pm \\
& 2.30 & & 2.23 & & 2.33 & & 2.08 & \\
\hline Circulatory system committee & 3.56 & \pm & 3.72 & \pm & 5.94 & \pm & 8.19 & \pm \\
& 1.50 & & 1.57 & & 1.05 & & 0.93 & \\
\hline $\begin{array}{l}\text { Sensory and nervous system } \\
\text { committee }\end{array}$ & 5.26 & \pm & 6.23 & \pm & 7.35 & \pm & 7.92 & \pm \\
\hline
\end{tabular}

Table 2. The results obtained in the examinations in the installation tissue biology committee 


\begin{tabular}{|l|l|l|l|l|}
\hline Groups & $\begin{array}{l}\text { Female students } \\
(\mathbf{n = 1 5})\end{array}$ & $\begin{array}{l}\text { Male students } \\
(\mathbf{n = 1 5})\end{array}$ & $\mathbf{Z}$ & $\mathbf{P}$ \\
\hline $\begin{array}{l}\text { Group 1 } \\
(\mathbf{n}=\mathbf{3 0})\end{array}$ & $6.16 \pm 2.50$ & $6.13 \pm 2.11$ & -0.133 & 0.744 \\
\hline $\begin{array}{l}\text { Group 2 } \\
(\mathbf{n = 3 0})\end{array}$ & $6.68 \pm 2.52$ & $6.52 \pm 1.95$ & -0.123 & 0.810 \\
\hline $\begin{array}{l}\text { Group 3 } \\
(\mathbf{n = 3 0})\end{array}$ & $7.56 \pm 2.44$ & $7.43 \pm 2.22$ & -0.853 & 0.415 \\
\hline $\begin{array}{l}\text { Group 4 } \\
(\mathbf{n}=\mathbf{3 0})\end{array}$ & $8.06 \pm 2.20$ & $7.89 \pm 1.96$ & -0.159 & 0.857 \\
\hline
\end{tabular}

Table 3. The results obtained in the examinations in the installation circulatory system committee.

\begin{tabular}{|l|l|l|l|l|}
\hline Groups & $\begin{array}{l}\text { Female students } \\
(\mathbf{n = 1 5})\end{array}$ & $\begin{array}{l}\text { Male students } \\
(\mathbf{n = 1 5})\end{array}$ & $\mathbf{Z}$ & $\mathbf{P}$ \\
\hline $\begin{array}{l}\text { Group 1 } \\
(\mathbf{n}=\mathbf{3 0})\end{array}$ & $3.66 \pm 1.39$ & $3.46 \pm 1.62$ & -0.684 & 0.494 \\
\hline $\begin{array}{l}\text { Group 2 } \\
(\mathbf{n}=\mathbf{3 0})\end{array}$ & $4.12 \pm 1.57$ & $3.32 \pm 1.58$ & -0.712 & 0.476 \\
\hline $\begin{array}{l}\text { Group 3 } \\
(\mathbf{n}=\mathbf{3 0})\end{array}$ & $5.96 \pm 0.98$ & $5.92 \pm 1.12$ & -0.086 & 0.931 \\
\hline $\begin{array}{l}\text { Group 4 } \\
(\mathbf{n}=\mathbf{3 0})\end{array}$ & $8.12 \pm 0.96$ & $8.26 \pm 0.91$ & -0.155 & 0.007 \\
\hline
\end{tabular}

Table 4. The results obtained in the examinations in the installation sensory and nervous system committee.

\begin{tabular}{|l|l|l|l|l|}
\hline Groups & $\begin{array}{l}\text { Female } \\
\text { students }(\mathbf{n = 1 5})\end{array}$ & $\begin{array}{l}\text { Male students } \\
(\mathbf{n = 1 5})\end{array}$ & $\mathbf{Z}$ & $\mathbf{P}$ \\
\hline $\begin{array}{l}\text { Group 1 } \\
(\mathbf{n = 3 0})\end{array}$ & $5.26 \pm 1.50$ & $5.27 \pm 1.87$ & -0.129 & 0.898 \\
\hline $\begin{array}{l}\text { Group 2 } \\
(\mathbf{n = 3 0})\end{array}$ & $6.28 \pm 1.02$ & $6.18 \pm 1.44$ & -0.113 & 0.910 \\
\hline $\begin{array}{l}\text { Group 3 } \\
(\mathbf{n = 3 0})\end{array}$ & $7.36 \pm 2.04$ & $7.35 \pm 1.56$ & -0.823 & 0.410 \\
\hline $\begin{array}{l}\text { Group 4 } \\
(\mathbf{n = 3 0})\end{array}$ & $7.96 \pm 1.30$ & $7.89 \pm 1.54$ & -2.666 & 0.008 \\
\hline
\end{tabular}

In the class of Tissue Biology, there was an increase in mean scores from group 1 to group IV, and there was not a statistically significant difference among groups ( $>>0.05)$. In the class of Circulatory System, following the theoretical class, the mean scores of the students who performed practical application both on model and on cadaver were prominently higher than the others. This difference was statistically significant $(\mathrm{p}<0.05)$.

In the class of Sensory and Nervous System, the mean scores of the students 
at group III and IV were statistically significant and higher than the other two groups $(\mathrm{p}<0.05)$.

\section{DISCUSSION}

Ina study including 191 medical school second-grade students, Ar1 et al. noted that $91.1 \%$ of the students thought cadavers should be used in order to learn the anatomy. In the same study, it was found that $46.6 \%$ of the students thought training on cadaver should be practised with the instruction of anatomists in practice courses, while $7.9 \%$ of the students thought it should be practised entirely by the students ${ }^{2}$.

Büyükmumcu et al. applied a survey to the 113 medical school second-grade students and found that almost all of the students reported there should be cadavers in anatomy practice. In the same study, $24.7 \%$ of the students noted that images related to cadavers should be added to the course slides used in the education of anatomy practice ${ }^{5}$.

For Aziz et al., cadaver-based anatomical education is a prerequisite for using the biomedical knowledge most appropriately. Cadaver dissection brings students in scientific skills, and it is also necessary for them to gain moral, ethical and humanistic approach towards patients ${ }^{6}$.

Anatomists involved in Ögenler et al.'s survey noted that studying on cadaver is superior to three-dimensional modelling and model usage ${ }^{7}$. In our study, at the classes of Circulatory System and Sensory-Nervous Systems, the success levels of the students at group III and IV were higher than the other groups. This result that is also statistically significant shows that anatomy practical training together with cadaver dissection eases students' comprehension and increases their success levels.

In addition to the researchers believing that cadaver dissection is important in anatomy education, there are also some researchers reporting that using anatomical models and radiological images provide great benefits for understanding the human anatomy ${ }^{8-11}$.
Bacro et al. indicated that computeraided education has recently been included in medical curriculum in order to decrease the costs and save time ${ }^{4}$.

Azer and Eizenberg emphasized that cadaver dissections play an important role in deeply understanding the anatomic structures and in remembering what is learned with three-dimensional point of view. Interestingly, however, they noted that innovations such as multimedia resources used in anatomy education did not create a change in students' perceptions on the importance of dissection ${ }^{12}$.

McLachlan et al. claimed that cadaver does not entirely resemble live human body especially in terms of colour and appearance, results obtained from palpation, percussion and incision are different from those of live human body, and thus cadaver is not an appropriate educational tool ${ }^{13}$.

Ashraf Aziz et al. reported that cadavers might infect diseases such as AIDS, hepatitis and tuberculosis ${ }^{9}$.

Furthermore, besides medical and educational drawbacks, several practical and economical drawbacks lead to keeping away from cadaver use; in this context, researchers pointed out that there aredifficulties in providing cadaver, and that keeping and maintaining the cadaver necessitate special equipment and suitable space 9,13 .

In Ar1 et al.'s survey study, $92.1 \%$ of the students believed that supplementary course materials as well as cadavers should be utilized in anatomy applications. When students were asked to compare the models used as supplementary course materials and cadavers, $13.1 \%$ of them chose models, $15.7 \%$ chose cadaveric study, and $68.1 \%$ chose both of them ${ }^{2}$.

In another survey study carried out by An and Sendemir, although $92.2 \%$ of the students noted that anatomy education cannot be performed without cadaver, $87.2 \%$ of the students said that new supplementary education materials and methods would ease their understanding the anatomic formations ${ }^{14}$. 
In this study aiming at researching the effect of studying with anatomic models and cadaver dissections on learning the anatomy, that the success levels of the students at group III and IV are higher than the other groups in all three classes shows that anatomy practical trainings given with cadaver dissections ease students' understanding and increase their success levels.

\section{REFERENCES}

1. Özdemir ST, Cankur NŞ, Kurt MA. Tıp Fakültesi Öğrencilerinin Anatomi Uygulamaları Hakkındaki Görüşleri: Bir

Geri Bildirim Örneği. Uludă̆ Üniversitesi Tip Fakültesi Dergisi 2001; 27: 39-42.

2. Ar1 İ, İrgil E, Kafa İM, Şendemir E. Bir Anket Çalışması: Anatomi Eğitimi ve Öğrencilerin Düşünceleri. Uludağ Üniversitesi Tıp Fakültesi Dergisi 2003; 29: $15-8$.

3. Türk Anatomi Ve Klinik Anatomi Derneği Yönetim Kurulu. Türkiye'de Kadavra Sorunu ve Çözüm Önerileri Nisan -2013, Sf.3-7.

4. Bacro T, Gilbertson B, Coultas J. Webdelivery of anatomy video clips using a CD-ROM. Anatomical Record 2000; 261: 78-82.

5. Büyükmumcu M, Aydın AD, Akın D, Yılmaz MT, Bodur AS. Tip Fakültesi Öğrencilerinin Anatomi Pratik Derslerinde Kullanılan Pratik Ders Slaytları Hakkındaki Görüşleri. Selçuk Tip Dergisi 2013; 29:71-4.

6. Aziz MA, McKenzie JC, Wilson JS, Cowie RJ, Ayeni SA, Dunn BK. The human cadaver in the age of biomedical informatics. Anat Rec 2002; 269: 20-32.

7. Ögenler O, Kara A, Kadıŏglu S, Öztürk AH, Sungur MA. Bir grup anatomi ögretim elemanının kadavra ve eğitimde kadavra kullanma hakkındaki görüşleri. Opinions of a group of anatomy instructor on cadaver and utilization of cadaver in anatomy teaching. Türkiye Biyoetik Dergisi 2014; 1: 57-68.
8. Arraez-Aybar LA, Catano-Collado G, Casado Morales M.I. Dissection from the Spanish anatomist's perspective: aims, attitude and related aspects. Rec Anat 2004; 281B: 15-20.

9. Ashraf Aziz M, Mckenzie JC, Wilson JS, Cowie RJ, Ayeni SA, Dunn BK. The human cadaver in the age of biomedical informatics. Anat Rec 2002; 269: 20-32.

10. Drake RL, Lowrie DJ, Prewitt CM. Survey of gross anatomy, microscopic anatomy, neuroscience, and embryology courses in medical school curricula in the United states. Anat Rec 2002; 269: 11822.

11. Miller SA, Perrotti W, Silverthorn DU, Dalley AF, Rarey KE. From college to clinic: reasoning over memorization is key for understanding anatomy. Anat Rec 2002; 269: 69-80.

12.Azer SA, Eizenberg N. Do we need dissection in an integrated problem-based learning medical course? Perceptions of first- and second-year students. Surg Radiol Anat 2007; 29: 173-80.

13. McLachlan JC, Bligh J, Bradley1 P, Searle J. Teaching Anatomy without Cadavers. Medical Education 2004; 38 : 418-24.

14.Arı İ, Şendemir E. Anatomi Eğitimi Üzerine Öğrenci Görüşleri. Uludağ Üniversitesi Tıp Fakültesi Dergisi 2003; 29: 11-14. 